\title{
Reappraising the Chinese School of International Relations: A postcolonial perspective
}

\author{
Yih-Jye Hwang* \\ Leiden University, The Hague, Netherlands \\ ${ }^{*}$ Corresponding author. Email: y.c.huang@luc.leidenuniv.nl
}

(Received 29 July 2020; revised 31 January 2021; accepted 1 March 2021; first published online 12 April 2021)

\begin{abstract}
This article aims to revisit the enterprise of the Chinese School (CS) of IR and discuss how it should be viewed and handled in the discipline, specifically from within the analytical framework of the power/resistance nexus put forward by Foucault, Bhabha, and Spivak. The argument of this article is twofold. Firstly, the CS attempts to reinvigorate traditional Chinese concepts (that is, humane authority, the Tianxia system, and relationality), which mimick Western mainstream IR. These concepts channel the CS into a realist notion of power, a liberal logic of cosmopolitanism, and a constructivist idea of relationality. Thus, the CS uses against the West concepts and themes that the West currently use against the nonWestern world. Nevertheless, as the second part of the argument will demonstrate, the enterprise of the CS can still be justified because it can be regarded as a reverse discourse; mimicking yet altering the original meanings of the taken-for-granted concepts, ideas, and principles used by mainstream IR scholars. Moreover, with the judicious use of strategic essentialism, the CS can potentially be one local group in a wider effort to contest diffused and decentred forms of Western domination through linking various struggles to form a unified 'counter-hegemonic bloc' of post-Western IR in the discipline.
\end{abstract}

Keywords: The Chinese School; Post-Western IR; Postcolonialism; Mimicry; Strategic Essentialism; Resistance

\section{Introduction}

As early as 1977, Stanley Hoffmann claimed that International Relations (IR) is an American social science, ${ }^{1}$ and according to Arlene B. Tickner, ${ }^{2}$ little has changed since then. Mainstream IR scholars (for example, realists, liberals, and constructivists) perceive different regions of the world as test cases for their theories rather than as sources for theory in themselves. Thereby, the 'non-West' became a domain that IR theorists perceived as backward; a domain which requires instruction in order to reach the 'end of history' that Western modernity encapsulates. ${ }^{3}$ One could say that the field of IR today has yet to sufficiently address how key processes that shape the practice of international relations elsewhere can tell us more about global politics as a whole. Over the past two decades, non-Western, post-Western, and global quests have emerged in IR that urge scholars to 'reworld' the 'subaltern voice'.

From the perspectives of those that seek to 'reworld' the 'subaltern voice', there is no single modernity to which all actors must aspire and no actor or set of actors is reified by theory. Rather, they seek out the hidden voices that intersect across the world. ${ }^{4}$ One of the main strategies

\footnotetext{
${ }^{1}$ Stanley Hoffmann, 'An American social science: International Relations', Daedalus, 106 (1977), pp. 41-60.

${ }^{2}$ Arlene B. Tickner, 'Core, periphery and (neo)imperialist International Relations', European Journal of International Relations, 19:3 (2013), pp. 627-46.

${ }^{3}$ Francis Fukuyama, The End of History and the Last Man (London: Penguin Books, 1992).

${ }^{4}$ See, for instance, Arlene B. Tickner and David L. Blaney (eds), Thinking International Relations Differently (London: Routledge, 2012).

(C) The Author(s), 2021. Published by Cambridge University Press on behalf of the British International Studies Association. This is an Open Access article, distributed under the terms of the Creative Commons Attribution licence (http://creativecommons.org/licenses/by/4.0/), which permits unrestricted re-use, distribution, and reproduction in any medium, provided the original work is properly cited.
} 
of such quests is to rediscover the lost historical and contemporary voices of the non-Western world. More specifically, they urge IR scholars to 'reworld' non-Western sites by examining how Western discourses of IR have been interpreted and appropriated at each particular site. The 'worlding' of the subaltern, if successful, would expose not only the 'provincial' characteristics of the West, but also the discursive nature of mainstream IR theories, which have both mistakenly presented themselves as universal truth, experience, and theory, a result of Eurocentrism backed up and reinforced by the power of expansion (for example, imperialism and neocolonialism).

A rising China has inspired great interest in the studies of international relations from a Chinese perspective. Many Chinese scholars argue that there should be a Chinese School (CS) of IR theory, and there have been various attempts to establish a Chinese theory of international relations over the past decade. Chinese IR scholars are dissatisfied with being consumers of knowledge rather than knowledge producers. ${ }^{5}$ Among others, ${ }^{6}$ Yan Xuetong's moral realism, Zhao Tingyang's conception of the Tianxia system, and Qin Yaqing's relational theory of world politics are the most representative and influential of this movement. Despite different focuses on the methods, concepts, and approaches that characterise the CS, all of them have tried to de-peripheralise China in the world of theory. They do so by resorting to China's historical experiences and ideas derived from traditional philosophies in order to understand, explain, and interpret world politics in a distinctively Chinese way. They all believe that the development of the mainstream IR theories is centred around Western values and philosophy that is based on a special collective memory of Western/European history and culture.

The popularity of the CS is nascent, but it has the potential to make an important contribution to non-Western, post-Western, and global quests in IR. Despite this potential, the CS has received a great deal of criticism in the anglophone world; mainstream IR scholars and critical IR scholars alike are sceptical of this movement's contribution to their respective fields. Critics, especially those from the critical IR perspective, have argued that the enterprise of the CS from the perspective of critical IR cannot be justified because: (1) it essentialises and fixates the existence of 'Chinese culture', which is fluid, multiple, heterogeneous, and above all, hybrid; and (2) it has the potential to be just another hegemonic design in favour of a different hegemon. This article aims to reappraise the aforementioned critical IR critiques of the CS. To this end, it will revisit the enterprise of the CS and discuss how it should be viewed and handled in critical IR, specifically from within the analytical framework of the power/resistance nexus put forward by Michel Foucault, Homi K. Bhabha, and Gayatri C. Spivak.

The argument of this article is twofold. Firstly, attempts to reinvigorate traditional Chinese concepts (that is, humane authority, the Tianxia system, and relationality) are mimicking Western mainstream IR. These concepts channel the Chinese Schools of IR into a realist notion of power, a liberal logic of cosmopolitanism, and a constructivist idea of relationality. Thus, the CS uses concepts and themes against the West that mainstream IR currently use against the non-Western world. CS's appropriation and reversal of mainstream IR theories is a strategy of cultural resistance, that is, to transform the language or concepts of the West into a hybrid text in a 'colonial mimicry', thereby resisting the hegemony of Western mainstream IR. The

\footnotetext{
${ }^{5}$ Xiao Ren, 'The road of independent development: The debate of the "Chinese School”' [in Chinese], International Politics Quarterly, 30:2 (2009), p. 16.

${ }^{6}$ It is noted that my coverage of the Chinese School writings is not exhaustive. There are many other scholars who are making important contributions to the Chinese School, including but not limiting to the balance of relations theory by Taipei-based scholars Chih-yu Shih and Chiung-Chiu Huang, the gongsheng (symbiosis) theory by Shanghai-based scholars like Shoujun $\mathrm{Hu}$ and Yingzhong Jin, and individual works by Shiping Tang. For the balance of relations theory, see Chih-yu Shih et al., China and International Theory: The Balance of Relationships (London: Routledge, 2019); for the gongsheng theory, see Xiao Ren et al., Gòngshēng: Shànghǎi Xuépài de Xīngqǐ [Symbiosis: The Rise of the Shanghai School] [in Chinese] (Shanghai: Shanghai Translation Publishing House, 2015).

${ }^{7}$ Homi K. Bhabha, The Location of Culture (London: Routledge 1994).
} 
enterprise of the CS can therefore be justified from a postcolonial perspective because it can be regarded as a reverse discourse, mimicking yet altering the original meanings of concepts, ideas, and principles used and taken for granted by mainstream IR scholars. Secondly, the enterprise of the CS does indeed problematically essentialise and fixate the existence of a 'Chinese culture', and has the potential to be another hegemonic construct based on Sinocentric ideology. Yet, with the judicious use of strategic essentialism, it can still be an important local discourse in a wider effort to contest diffused and decentred forms of Western domination through linking various struggles to form a unified 'counter-hegemonic bloc' of post-Western IR in the discipline.

In what follows, this article will first elucidate Yan's moral realism, Zhao's conception of the Tianxia system, and Qin's relational theory of world politics and how they have been received in the West. Afterwards, the article will offer a defence of the CS, drawing on Bhabha's notion of 'mimicry' and Spivak's idea of 'strategic essentialism' within Foucault's analytical framework of the 'power/resistance nexus'.

\section{Mimicking Western perspectives in the Chinese School: Yan Xuetong's moral realism, Zhao Tingyang's Tianxia system, and Qin Yaqing's relational theory of world politics}

In August 1987, at the first National Congress of International Relations Theory held in Shanghai, the establishment of China's own theoretical system of international relations became the core issue of the meeting. From this point, the call for IR theories with Chinese characteristics, the Chinese perspective, and eventually the creation of a Chinese School that encapsulated both of these features have appeared one after another. Chinese IR scholars were dissatisfied with being consumers of knowledge, instead seeking to become knowledge producers. ${ }^{8}$ For them, the core of constructing the Chinese School is to examine IR theories through Chinese experiences and incorporate more Chinese perspectives and traditional thinking. ${ }^{9}$ In this section, I will briefly explain the theories of the three most representative and influential Chinese scholars in this movement, namely: Yan Xuetong's moral realism, Zhao Tingyang's conception of the Tianxia system, and Qin Yaqing's relational theory of world politics.

In 2005 a research team led by Yan Xuetong - a Chinese foreign policy analyst and IR theorist at Tsinghua University in Beijing - initiated a project that aimed to develop a new IR theory on the basis of pre-Qin Chinese thinking to 'enrich contemporary international relations theory and present findings relevant to China's foreign policy..${ }^{10}$ In Yan's view, pre-Qin China was the greatest period for Chinese thought as it saw several philosophical schools compete for ideological supremacy and political influence. Therefore, this period can provide novel insights and inspirations for our understanding of China's rise and what implications it may have for China and for the world. Yan's project is divided into three phases. ${ }^{11}$

The first phase aims to survey the political philosophy of the pre-Qin classics that contain some primitive and distinctive ideas of interstate relations. In 2008, selected readings of Chinese pre-Qin Political Thought, edited by Yan and Xu Jin, ${ }^{12}$ were published by Fudan University Press. The book features original texts with introductory notes, translations into modern Chinese, and questions for further discussion. In the second phase, Yan and his team systematically theorise the interstate political thought drawn from the several pre-Qin thinkers. During

\footnotetext{
${ }^{8}$ Ren, 'The road of independent development', p. 16.

${ }^{9}$ See Yaqing Qin, 'A Chinese School of International Relations theory: Possibility and inevitability' [in Chinese], World Economics and Politics, 2006:3 (2006), pp. 7-13.

${ }^{10}$ Xuetong Yan, Daniel A. Bell, and Sun Zhe (eds), Ancient Chinese Thought, Modern Chinese Power, trans. E. Ryden (New Jersey: Princeton University Press, 2011), p. 21.

${ }^{11}$ Jin Xu and Xuefeng Sun, 'The Tsinghua approach and the future direction of Chinese international relations research' [in Chinese], World Outlook, 2014:6 (2014), pp. 18-32.

${ }^{12}$ Xuetong Yan and Jin Xu (eds), Pre-Qin Chinese Thoughts on Foreign Relations [in Chinese] (Shanghai: Fudan University Press, 2008).
} 
this phase, Yan and his colleagues published their works mainly in Chinese journals, which were later on assembled into an edited volume. ${ }^{13}$ Meanwhile, their works also attracted the attention of the international academic community. The English version of the collection of three of Yan's essays, accompanied by three corresponding commentaries by other Chinese scholars followed by Yan's response, was published by Princeton University Press in $2011{ }^{14}$ The third phase focuses on a set of historical cases to examine the theory developed from the second phase. Important works during this period include Zhou Fangyin's and Xu Jin's studies of various historical cases. ${ }^{15}$

In essence, Yan argues that in ancient Chinese thought, political power was the key to international relations for the state, and the central attribute of political power was morally informed leadership, or what he called Wangdao (the term literally means the 'kingly way' and Yan translates it as 'humane authority'). Yan identified with realism, an approach that sees power as an irreducible element of the political sphere. However, instead of simply following the mainstream IR realists' notion of power, Yan believes in the need for a new exploration of alternative conceptions and operations of power from a distinctive Chinese perspective. According to Yan, ${ }^{16}$ there are three different ways in which governmental power can be wielded in Chinese political thought - qiang (tyranny), ba (hegemony), and wang (humane authority). ${ }^{17}$ Yan argues that the humane authority style of leadership is regarded in Xunzi's and other Confucian thoughts as the highest and most prized form of government. It is superior to the other two, qiang and $b a$, which are equivalent to the Western notion of hard power. Yan's theory draws largely on the notion of 'humane authority' to provide a different understanding of the operation of power and leadership in world politics.

What is humane authority? As Yan elaborated, at the core of humane authority thinking is 'benevolence', 'righteousness', and 'rite'. ${ }^{18}$ It is about 'practicing' those virtues and moralities in order to be accepted by others as the world leader, ${ }^{19}$ or in a Chinese term, yishen zuoze (literally meaning leading by example). Humane authority is therefore not something that one can strive for; rather, it is acquired by setting an example of virtues and moralities and winning the hearts of the people by doing so. In this vein, virtues and moralities are qualities that can be inherent in the conduct of the state and its leaders, and which can influence others to act in one's favour and become the source of political power. Yan named this the 'example-emulation' model, ${ }^{20}$ which is fundamentally different from the normative persuasion model proposed by Ikenberry and Kupchan and normally implemented by the Western powers. To Yan, the persuasion model emphasises that the hegemonic state persuades other states to follow the international norms it advocates through its discursive power (and/or soft power). On the other hand, he

\footnotetext{
${ }^{13}$ Xuetong Yan and Jin $\mathrm{Xu}$, Wang Ba Tianxia Thought and Enlightenment [in Chinese] (Beijing: World Affairs Press, 2009).

${ }^{14}$ Yan et al., Ancient Chinese Thought.

${ }^{15}$ Fangyin Zhou, 'Legitimized rise under loose hierarchical system: An analysis of the vassals' "zunwang" strategy in the spring and autumn Period' [in Chinese], World Economics and Politics, 2012:6 (2012), pp. 4-34; Fangyin Zhou, 'Equilibrium analysis of the tributary system', The Chinese Journal of International Politics, 4:2 (2011), pp. 147-78; Jin $\mathrm{Xu}$, 'Effectiveness analysis of the strategy of "revering the emperor and expelling the barbarians" in the spring and autumn period' [in Chinese], Quarterly Journal of International Politics, 2012:2 (2012), pp. 38-61.

${ }^{16}$ Yan et al., Ancient Chinese Thought.

${ }^{17}$ Yan in his 2019 book identifies four types of leadership in international relations, namely: 'humane authority' (that is, trustworthy), 'hegemony' (that is, trustworthy but follows a double standard), 'tyranny' (that is, untrustworthy but consistent), and 'anemocracy' (that is, untrustworthy and follows a double-standard); the double-standard for hegemony and anemocracy refers to the practice of acting well towards allies but poorly towards rivals. See Xuetong Yan, Leadership and the Rise of Great Powers (Princeton, NJ: Princeton University Press, 2019), pp. 25-53.

${ }^{18}$ Xuetong Yan, 'New values for new international norms' [in Chinese], China International Studies, 38 (2013), pp. 15-28.

${ }^{19}$ Xuetong Yan, 'International leadership and norm evolution', The Chinese Journal of International Politics, 4:3 (2011), pp. 233-64.

${ }^{20}$ Yan, Leadership, pp. 113-15.
} 
believes that the example-emulation model differs due to the leading state acting as a role model rather than persuading, leading other states to follow suit voluntarily without direct interference. Yan contextualises morality in the realist tradition by arguing that it is not a set of values that a state must follow, but is instead an instrument to implement the strategic preferences of the nation, which would allow them to achieve their interests while also gaining support from other states. $^{21}$ Yan's theory is therefore known as moral realism. ${ }^{22}$

While Yan and his team have utilised the term 'humane authority' to reconceptualise the notion of power from a Chinese perspective, other works published by Chinese scholars have attempted to acquire and appropriate theories and practices of Tianxia, an ancient Chinese notion that dates back to the imperial times in China, in answering the call for the CS of IR. This notion has inspired a range of Chinese scholars to formulate ambitious plans for China's future. Among others, Zhao Tingyang, a professor in the Institute of Philosophy at the Chinese Academy of Social Sciences, is the most prominent Chinese intellectual to date to discuss how China would change the world order through the application of Tianxia.

Since the first publication of The Tianxia System: A Philosophy for the World Institution in $2005,{ }^{23}$ Zhao has been promoting the idea of Tianxia as a philosophy of a world system that transcends the perspective of the nation state so that all must look at all without excluding anyone. According to Zhao, political theorists in the West are mainly concerned about the political life in terms of the individual, community, and nation-state. In contrast, the Chinese tradition looks to the levels of the world (that is, Tianxia), state, and family. Zhao noted that Kant's peace theory contains both an idealistic fantasy and a realist vision. Its idealistic fantasy is a 'world republic' composed of 'world citizens' - turning the world into an extraordinary large-scale country. However, Kant himself rejected this illusion and recommended a more realistic plan, namely a 'free federation', a peace alliance composed of 'free nations'. For Zhao, Kant's theory is undoubtedly great, but the limitations of its peace conditions make it impossible to explain and solve world-scale peace problems. ${ }^{24}$ The Westphalian world order inevitably leads to conflict in world politics due to its nature being primarily based on competing national interests. Due to the limitations of Western political theory, with the nation-state as the largest political unit, Zhao suggests that we need to transcend the principle of 'internationality' and think about the world from a truly global perspective. Here, Zhao draws from an idealised version of the Tianxia system of the Zhou dynasty (c. 1046-256 BC) as the paradigmatic model and argues that the system as alternative approach to Kant's 'world republic' would solve world-scale peace problems through its world institution.

What is the Tianxia system? According to Zhao, the Tianxia system in the Zhou dynasty was an all-inclusive geographical, psychological, and institutional term. It operated on three levels: (1) the earth, that is, all lands under the sky; (2) a common or public choice made by all peoples in the world, truly representing the general will; and (3) a universal political system for the world. Zhao therefore believes that, in the ontology of Tianxia, the entirety of the world is the unit of analysis, and subsystem units, such as the nation-state, distract from the analysis on the systemic level and thus they are excluded. ${ }^{25}$ Within the system of Tianxia no distinction is made between 'them' and 'us' since all stay what they are internally. ${ }^{26}$ In other words, the system has only internality, and there will be no more insurmountable externalities. The system therefore belongs to all

\footnotetext{
${ }^{21}$ Ibid., p. 7.

${ }^{22}$ See Feng Zhang, 'The Tsinghua approach and the inception of Chinese theories of international relations', Chinese Journal of International Politics, 5:1 (2012), pp. 95-6.

${ }^{23}$ Tingyang Zhao, Tianxia Tixi (Nanjing: Jiangsu Jiaoyu Chubanshe, 2005).

${ }^{24}$ Tingyang Zhao, 'Tiānxià zhìxù de wèilái xìng [The future of the world order]' [in Chinese], Exploration and Free Views, 2015:11 (2015), pp. 7-21.

${ }^{25}$ Tingyang Zhao, 'A political world philosophy in terms of all-under-heaven', Diogenes, 56:1 (2009), p. 9.

${ }^{26}$ Tingyang Zhao, 'Rethinking empire from a Chinese concept "all-under-heaven”', Social Identities, 12:1 (2006), pp. 2941.
} 
humans equally and is more peace-driven than the Westphalian system that has dominated the world order for centuries. Zhao's project can therefore be regarded as an attempt to create a holistic entity of humanity, a world of oneness, a Chinese version of liberal cosmopolitanism or perpetual peace.

It is important to note that Zhao's Tianxia system is a utopia that has practical applications. By resembling Rawls's idea of original position, Zhao conducts a thought experiment that aims to reflect what principles of global governance would be manifest in the Chinese tradition premised on the holistic entity of humanity. Moreover, Zhao does not intend to 'equate his Tianxia system with the ancient Chinese tributary system'. ${ }^{27}$ According to Zhao, ${ }^{28}$ the unification of China from the Qin to the Qing dynasty was a 'country containing the world'. The fundamental characteristic of unified China since the Qin dynasty inherited the spiritual heritage of the Tianxia concept but gave up the world institution. In other words, China transformed 'the Tianxia spirit into a state spirit, changing a world structure into a state structure and consequently turning China into a "world-structured" country'. ${ }^{29}$ In this vein, Zhao only attempts to utilise the original meaning of Tianxia as derived from the Zhou dynasty and not how it was practiced after the Qin dynasty in order to propose a plausible practice (and way of thinking) for world governance. ${ }^{30}$ Nor does his theory imply that China should lead the world either. As Zhao suggests, the system is open to any qualified candidates who best know the Way (dao) to improve the happiness of all peoples universally.' ${ }^{31}$ That said, Zhao implicitly suggests that China can contribute to the establishment of the world institution, since the 'Tianxia spirit' has remained constant in the process of the formation of China today. ${ }^{32}$

Like Yan and Zhao, Qin Yaqing of the China Foreign Affairs University in Beijing suggests that ancient Chinese political thought offers a different approach to global problems. Qin is one of the pioneers and main advocates of the need to construct the CS of IR based on Chinese cultural traditions. It is not surprising that Qin explores Chinese cultural and philosophical traditions as sources to develop an IR theory, especially when considering his intellectual background. Qin was trained in the US and received his $\mathrm{PhD}$ at the University of Missouri, Columbia. Most of his earlier works were hugely influenced by social constructivism in IR, which sees state behaviours as shaped by cultural factors such as culture, norms, and identity. In 2009, Qin first proposed the idea of processual constructivism, ${ }^{33}$ and strengthened the theoretical discussion in the following years. ${ }^{34}$ Since 2015 , Qin officially put forward the relational theory of IR which theorises the Chinese notion of 'relationality' as the core of his theory. ${ }^{35}$ His theory entails four basic assumptions: (1) relationality is the basic unit for analysing the social world; (2) rationality is embedded within relationality; (3) relationality determines identity; and (4) relationality generates power.

First of all, according to Qin, Chinese society places great emphasis on relationality, or guanxi, an idea that is embedded in Confucianism. As Qin explained, Chinese society is guided by an immanent Confucian cosmos, which can be understood as 'everything being in everything else', meaning that everything is related to one another and to the context. In the Chinese

\footnotetext{
${ }^{27}$ Bijun Xu, 'Is Zhao's Tianxia system misunderstood?', Monde Chinois, 49:1 (2017), p. 48.

${ }^{28}$ Tingyang Zhao, Benefits to this China: China as a Divine Concept [in Chinese] (Beijing: CITIC Press Corporation, 2016).

${ }^{29}$ Tingyang Zhao and Liqing Tao, Redefining a Philosophy for World Governance (London: Palgrave Pivot, 2019), p. 22.

${ }^{30}$ Tingyang Zhao, A Possible World of All-under-the-Heaven System: The World Order in the Past and for the Future [in Chinese] (Beijing: CITIC Press Corporation, 2016).

${ }^{31}$ Zhao, 'Rethinking empire', p. 32. See also Xu, 'Is Zhao's Tianxia system misunderstood?', p. 47.

${ }^{32}$ Zhao and Tao, 'Redefining a philosophy', pp. 21-36.

${ }^{33}$ Yaqing Qin, 'Relationality and processual construction: Bringing Chinese ideas into International Relations theory', Social Sciences in China, 30:4 (2009), pp. 5-20.

${ }^{34}$ Yaqing Qin, 'International society as a process: Institutions, identities, and China's peaceful rise', The Chinese Journal of International Politics, 3 (2010), pp. 129-53; Yaqing Qin, 'Rule, rules, and relations: Toward a synthetic approach to governance', The Chinese Journal of International Politics, 4 (2011), pp. 117-45.

${ }^{35}$ Yaqing Qin, 'A relational theory of world politics', International Studies Review, 18:1 (2016), pp. 33-47.
} 
tradition, an individual makes decisions based on the degree of intimacy and hierarchical status (superior or inferior) with the totality of the relational context as the background. The world is interwoven with a series of 'relations'; actors are connected to each other and the environment. The Chinese social structure resembles ripples on a lake, with individuals situated at the centre of concentric and overlapping ripples. ${ }^{36}$ Therefore, unlike the modern Western worldview that is oriented towards an atomistic understanding of the individual and stresses individual liberal autonomy, the Chinese are predisposed to seeing and understanding the world within a relational context. $^{37}$

As a result, there is no transcendent 'absolutely rational actor'. A social actor must therefore first consider the relational context one is embedded in before taking a rational decision. In such an interrelated world, 'the totality of relations is like an intangible hand that orients a social actor towards a certain action'. ${ }^{38}$ In this vein, social actors are always embedded in 'relational circles', which guide and constrain the ways in which social actors might behave. Actors simply do not know whether the action is rational or not outside those circles. Thus, in contrast to a Western society that sees individuals as guided by rationality and self-interests, the Confucian society sees individuals as motivated by the need to maintain the continuity of relations within an interrelated society. This is because what matters to people who live in such a community is not individual agency, but collective agency. Therefore, from a Confucian perspective, there is no such thing as an 'absolute rational mind that can transcend the relational complexity'. ${ }^{39}$

Moreover, relations define identity, which shapes interests and behaviours. While Qin's theory accepts the basic tenet of Wendt's constructivism that identity defines interest, which then defines behaviour, Qin takes it a step further and adds relations as the 'prime mover' of behaviour. The identities and social roles of actors are determined by social relations, and there is no identity that separates from social relations. Moreover, social relations are not static, but a 'process', a manifestation of the fluidity of 'relationship'. The identity and social roles of actors are also constantly changing. Qin uses the analogy of the Chinese chess game, weiqi to illustrate this Confucian cosmos. In the Western game of chess, every piece has a predetermined identity, such as a king or a bishop. But in weiqi, all pieces are alike with no pre-fixed identities. Each piece gains its function and role through its relation to other pieces. Therefore, individuals are born as social beings into a relational web, with their identities, roles, and appropriate behaviours being given and defined by the relational web. ${ }^{40}$

And finally, relations generate power and power flows from relations. Qin contends that power is a reflection of intersubjective relational practice. From the relational perspective, a social actor is more powerful because he or she has larger relational circles, in which there are more important others, thereby giving him or her more social prestige. In this regard, relations in a Confucian setting become the 'tools' for instrumental purposes. Social actors actively make use of the relational circles for instrumental purposes, defined in terms of both immediate tangible and material gains, as well as the long-term intangible and nonmaterial, and above all, to maintain a social order in which each different individual actor lives in harmony with every other.

\section{Critics of the Chinese School of IR in anglophone scholarship}

As discussed in the previous section, the nascent popularity of the CS can be identified in various works of the Chinese scholars. Although some anglophone scholars welcome CS, ${ }^{41}$ it has also

\footnotetext{
${ }^{36}$ Qin, 'Relationality and processual construction'.

${ }^{37}$ Benjamin T. E. Ho, 'About face: The relational dimension in Chinese IR discourse', Journal of Contemporary China, 25:98 (2016), pp. 307-20.

${ }^{38}$ Qin, 'A relational theory', p. 38.

${ }^{39}$ Ibid., p. 36.

${ }^{40}$ Ibid.

${ }^{41}$ For instance, Qin's theory has been well received in the discipline in the anglophone world. The article by Nordin and Smith, for instance, both valorises Qin's contribution and critiques it. See Astrid H. M. Nordin and Graham M. Smith,
} 
received a great deal of criticism. These main criticisms of the CS can be summarised into the following categories.

The first main line of criticism focuses on the CS's alleged misunderstanding, misinterpretation, or romanticisation of Chinese political thought and history, which leads to problematic essentialisations of 'Chinese culture'. In June T. Dreyer's words, ${ }^{42}$ it is a kind of anachronism that is 'at best disingenuous and at worst dangerous'. The critics in this line argue that CS's references to historical documents and classics are either inaccurate or overly romanticised. Meanwhile, this line of criticism also infers an imperious form of Chinese exceptionalism - a wishful thinking that 'China will be different from any other great power in its behaviour or disposition'. ${ }^{43}$ In a plea for global IR, Amitav Acharya gives a word of warning that global IR scholars should avoid a 'cultural exceptionalism and parochialism' that presents 'the characteristics of one's own group (society, state, or civilisation) as homogenous, unique, and superior to those of others'. ${ }^{4}$

This line of criticism is particularly prominent in discussions of Yan's moral realism. As noted by some critics, ${ }^{45}$ Yan and his colleagues' analyses do not only risk anachronism, but also rely too much on their romanticised reading of ancient Chinese thought rather than being solidly grounded in the actual history of ancient China. The Confucian ideals presented in his project do not equate with the realities of Chinese history. Hence, they claim that Yan is actually 'building castles in the sand'. ${ }^{46}$ Specifically, critics argue that Yan's pre-Qin project overlooks the asymmetric use of hard power and soft/normative power, downplaying the actual primacy of the former in Chinese history and emphasising the latter. Wang Yuan-kang, in his series of work on China's premodern foreign relations during the period of Song and Ming dynasties, ${ }^{47}$ argues that the ideational power of Confucian pacifism was not so influential as had earlier been assumed. ${ }^{48}$ Ming China, for instance, was expansionist at the apex of its power, attacking the Mongols and annexing Vietnam as a Chinese province. Only for the sake of consolidating its dominance did Ming China use 'Confucian ideology to justify its hegemonic position within the tribute system'. ${ }^{49}$ Similar accusations of anachronism also occur in the criticism of Zhao's Tianxia system. Chang Chi-shen, ${ }^{50}$ for instance, asserts that Zhao's view on Tianxia system does not correspond to the historical form of the system during the Zhou dynasty. As Chang notes, the Tianxia system

\footnotetext{
'Relating self and other in Chinese and Western thought', Cambridge Review of International Affairs, 32:5 (2019), pp. 636-53. They also suggest that we should go beyond the dichotomy of the West and East and work towards a 'global relational theorizing'. See Astrid H. M. Nordin et al., 'Towards global relational theorizing: A dialogue between sinophone and anglophone scholarship on relationalism', Cambridge Review of International Affairs, $32: 5$ (2019), pp. 570-81; see also Emilian Kavalski, The Guanxi of Relational International Theory (London, Routledge, 2018).

${ }^{42} J u n e$ T. Dreyer, 'China's Tianxia: Do all under heaven need one arbiter?', Yale Global Online (2014), available at: \{https:// yaleglobal.yale.edu/content/chinas-tianxia-do-all-under-heaven-need-one-arbiter\} accessed 16 July 2020.

${ }^{43}$ Hun Joon Kim, 'Will IR theory with Chinese characteristics be a powerful alternative?', The Chinese Journal of International Politics, 9:1 (2016), p. 73. See also Feng Zhang, 'The rise of Chinese exceptionalism in International Relations', European Journal of International Relations, 19:2 (2013), pp. 305-28.

${ }^{44}$ Amitav Acharya, 'Global international relations (IR) and regional worlds', International Studies Quarterly, 58:4 (2014), p. 561 .

${ }^{45}$ Zhang, 'The Tsinghua approach'; Niv Horesh, 'In search of the "China model": Historic continuity vs. imagined history in Yan Xuetong's thought', China Report, 49:3 (2013), pp. 337-55; Lindsay Cunningham-Cross, 'Using the past to (re)write the future: Yan Xuetong, pre-Qin thought and China's rise to power', China Information, 26:2 (2011), pp. 219-33.

${ }^{46}$ Victoria T. B. Hui, 'Building castles in the sand: A review of ancient Chinese thought, modern Chinese power', The Chinese Journal of International Politics, 5:4 (2012), pp. 425-49.

${ }^{47}$ Yuan-kang Wang, Harmony and War: Confucian Culture and Chinese Power Politics (New York: Columbia University Press, 2010); Yuan-kang Wang, 'Managing regional hegemony in historical Asia: The case of early Ming China', The Chinese Journal of International Politics, 5:2 (2012), pp. 129-53.

${ }^{48}$ See also Victoria T. B. Hui, War and State Formation in Ancient China and Early Modern Europe (Cambridge: Cambridge University Press, 2005).

${ }^{49}$ Wang, 'Managing regional hegemony', p. 152.

${ }^{50}$ Chishen Chang, 'Tianxia system on a snail's horns', Inter-Asia Cultural Studies, 12:1 (2011), pp. $28-42$.
} 
did not span the globe during the Zhou dynasty; it only referred to those who were part of the political alliance of the Zhou dynasty. ${ }^{51}$ Thus, the system was designed as a ruling system that only sought to create legitimacy of the dynasty, rather than building a universalist narrative. ${ }^{52}$

With regards to Qin's works, critics point to the problematic dichotomy between Western and Chinese culture, and the difficulties in talking about the essentialised differences between Western and Chinese culture. One of the main criticisms of Qin's relational theory is that his conception of 'relationality' is not just a Chinese element, it exists in Western societies as well. Western theories also discuss relationships. There are many works in the anglophone world that discuss relationalism without drawing directly on Qin. While some of those approaches differ from Qin as they presuppose that state actors are rational actors, ${ }^{53}$ others - especially some works by poststructuralists such as L. H. M. Ling and Astrid H. M. Nordin, ${ }^{54}$ - are decidedly relational without falling back on rationalism. It is therefore not easy to distinguish Qin's relational theory from other theories that developed in the West, ${ }^{55}$ such as social network analysis, Bourdieu's field theory, Dewey's pragmatism, and structuration theory. ${ }^{56}$ As Nordin and Smith rightly point out, we need to move 'away from facile East-West dichotomization and from the claim that relationality is simply Chinese and rationality is simply Western'. ${ }^{57}$ Consequently, although Qin's relational theory is an important achievement, it cannot simply be said that it is the Chinese School of IR.

The second main line of criticism points to a danger that the intellectual resource of the CS might simply be serving the interests of the Chinese government in order to legitimise the rise of China, otherwise known as a 'Sino-empire'. As Nele Noesselt argues, 58 'the search for a "Chinese" paradigm of international relations theory is part of China's quest for national identity and global status'. It aims 'to safeguard China's national interests and to legitimise the one-party system'. ${ }^{59}$ Similarly, Acharya is also cautious of the relationship between the CS and the Chinese government. As he observes, ${ }^{60}$ some of the core ideas in the CS overlap with political slogans advocated by the Chinese government, which brings the risk of losing intellectual independence and making theory a tool for official policy. Indeed, it has been widely observed that the endeavour to establish the CS as an internal academic disciplinary development is closely linked to the external world, the rise of Chinese political power in global politics. ${ }^{61}$ The emergence of China as a major player

\footnotetext{
${ }^{51}$ Chishen Chang, “'Zhōngguó" yŭ "tiānxià" gàiniàn tàn yuán [The origin of the concepts of "China” and "world”]' [in Chinese], Soochow Journal of Political Science, 27:3 (2009), pp. 169-256.

${ }^{52}$ See also Zhaoguang Ge, 'Imagination of "the world": The politics, thoughts and academic behind a utopian imagination' [in Chinese], Reflexion, 29 (2015), pp. 1-56.

${ }^{53}$ See Patrick T. Jackson and Daniel Nexon, 'Relations before states: Substance, process and the study of world politics', European Journal of International Relations, 5:3 (1999), pp. 291-332.

${ }^{54}$ L. H. M. Ling, The Dao of World Politics: Towards a Post-Westphalian, Worldist International Relations (Abingdon: Routledge, 2014); L. H. M. Ling and Astrid H. M. Nordin, 'On relations and relationality: A conversation with friends', Cambridge Review of International Affairs, 32:5 (2019), pp. 654-68.

${ }^{55}$ Jackson and Nexon mapped the current topography of relational approaches in anglophone International Relations theory and categorise them into two clusters in the study of Western relationalism, namely: 'position' versus 'process'. See Patrick T. Jackson and Daniel H. Nexon, 'Reclaiming the social: Relationalism in anglophone international studies', Cambridge Review of International Affairs, 32:5 (2019), pp. 593-95.

${ }^{56}$ See Jackson and Nexon, 'Reclaiming the social'; Pierre Bourdieu and Loic J. D. Wacquant, An Invitation to Reflexive Sociology (Cambridge: Polity Press 1992); Anthony Giddens, The Constitution of Society: Outline of the Theory of Structuration (Cambridge: Polity Press, 1983).

${ }^{57}$ Nordin and Smith, 'Relating self and other', p. 648.

${ }^{58}$ Nele Noesselt, 'Revisiting the debate on constructing a theory of international relations with Chinese characteristics', The China Quarterly, 222 (2015), p. 430.

${ }^{59}$ Ibid.

${ }^{60}$ Amitav Acharya, 'Quánqiú guójì guānxì xué yŭ guójì guānxì līlùn de zhōngguó xuépài: Liăng zhě shìfǒu jiānróng [Global IR and the Chinese School of International Relations theory: Are they compatible?]' [in Chinese], World Economics and Politics, 2015:2 (2015), p. 15.

${ }^{61}$ See Hung-jen Wang, The Rise of China and Chinese International Relations Scholarship (Lanham, MD: Lexington Books, 2013).
} 
in world politics has fostered a new interest in Chinese traditional thought that serves to promote China's own worldview and interests as a way to justify China's position as a particular political power.

For instance, many Western scholars are anxious about the destiny of Zhao's Tianxia system being just another new hegemonic construction. William A. Callahan, ${ }^{62}$ one of the most ardent critics of Zhao, argues that Tianxia embraces a distinctively Chinese practice of hegemony. As Callahan states, ${ }^{63}$

[While] the Westphalian system is rightly criticised for being state-centric, the Tianxia example shows how non-Western alternatives can be even more state-centric. Moreover, proposals for a 'post-hegemonic' system often contain the seeds of a new (and often violent) system of inclusion and exclusion: Tianxia presents a popular example of a new hegemony where imperial China's hierarchical governance is updated for the twenty-first century.

Callahan goes further to question Zhao's motivation behind his theory. According to Callahan, the majority of the literature on Tianxia, including Zhao's theory, has focused on its potential as a resource for recentring China and the Chinese understandings of world order as a patriotic activity. Zhao's theory might not seem realistic, but it sketches an image of China that Beijing is striving for, an image that is mainly based upon making China the centre of the world through hard military power, economic power, and normative objectives.

Callahan's fierce criticism of Zhao's thesis has been widely shared among other scholars in the anglosphere IR world and beyond. ${ }^{64}$ The similarity between the critics of Zhao's thesis lies in their shared treatment of Tianxia as a resource to be appropriated strategically to undergird China's order and interests. To them, China appears as an owner of an initiative, an agency, and a different identity. ${ }^{65}$ They all believe that the use of the concept is a Chinese way of expanding so as to bolster a hierarchical world order since the social order and the international order in ancient China were mainly built upon a principle of hierarchy. Some even argue that Zhao's theory manifests China's desire to rebuild the Chinese tributary system. ${ }^{66}$ Zhao's Tianxia system therefore only marks a different type of imperialism, and is useless in advancing the theorisation of IR.

Likewise, Lindsay Cunningham-Cross and Callahan make similar criticism of Yan's moral realism. ${ }^{67}$ According to them, the problem in Yan's theory is not the insufficient discussion of morality in international relations. Rather, it is an excessive use of moral language, and the attempt to monopolise morality in ways that do not allow for pluralism. It is easy to position China as moral and just, while criticising the immorality and injustice of others (for example, the West). Moreover, they argue that 'Yan's appeal to hierarchical order is likely to be a hard-sell not only in the liberal West, but also among China's Asian neighbours and developing states

\footnotetext{
${ }^{62}$ William A. Callahan, 'Chinese visions of world order: Post-hegemonic or a new hegemony?', International Studies Review, 10:4 (2008), pp. 749-61.

${ }^{63}$ Ibid., p. 759.

${ }^{64}$ Allen Carlson, 'Moving beyond sovereignty? A brief consideration of recent changes in China's approach to international order and the emergence of the Tianxia concept', Journal of Contemporary China, 20:68 (2011), pp. 89-102; June T. Dreyer, 'The "Tianxia trope": Will China change the international system?', Journal of Contemporary China, 24:96 (2015), pp. 1015-31.

${ }^{65}$ One of the exceptions is the study conducted by Babones, who argues that the US should be the new 'middle kingdom' rather than China. See Salvatore Babones, American Tianxia: Chinese Money, American Power and the End of History (Bristol, UK: Policy Press, 2017).

${ }^{66}$ An explanation for that misreading of Zhao's text is that the understanding of the Tianxia system by those critics is predominated by a widespread discourse concerning Tianxia presented by Fairbank, who sees the Tianxia and tributary system interchangeable. See John K. Fairbank (ed.), The Chinese World Order: Traditional China's Foreign Relations (Cambridge: Harvard University Press, 1968).

${ }^{67}$ Lindsay Cunningham-Cross and William A. Callahan, 'Ancient Chinese power, modern Chinese thought', The Chinese Journal of International Politics, 4:4 (2011), pp. 349-74.
} 
worldwide.' Similarly, He Kai also states that it would be difficult to operationalise Yan's theory in the real world because there is no universal consensus on what principles of morality ought to be followed in international relations. '[There] is no Son of Heaven universally accepted and recognised in today's world politics' ${ }^{68}$ Inevitably, Yan's theory will simply allow China to use moral rhetoric for its own sake at the expense of others.

The above lines of criticism are valid but not entirely convincing given that the accusations are not unique to China - they can be easily applied to other great powers too. For instance, the phenomenon of American exceptionalism is ever-present in contemporary International Relations. ${ }^{69}$ Furthermore, Zhang heeded that Chinese exceptionalism, despite its selective use of China's rich traditions, can still become an important source of policy ideas for Chinese IR scholarship. ${ }^{70}$ Similarly, Noesselt's critique of the development of the CS as a part of China's quest for national identity, affirming global status, and safeguarding China's national interests is no different to American IR scholars across different schools that do exactly the same thing. Regardless of whether or not it is fair to take Yan's, Zhao's, or Qin's works as the theoretical justification for a particular political power, mainstream IR theoretical perspectives are always for the purpose of securing an international system designed for the security and interests of the hegemonic power, that is, the US. ${ }^{71}$ Liberalism in IR, for instance, can arguably be regarded as nothing more than a rationalisation for American/Western hegemony over the rest of the world, let alone political realists' scholarly works. As Edward H. Carr noted in his letter to Hoffman in $1977,{ }^{72}$

What is this thing called international relations in the 'English speaking countries' other than the 'study' about how to 'run the world from positions of strength'? In other places, at other times, it might be something else, but within those states which had the influence - as opposed to those that did not - it was little more than a rationalization for the exercise of power by the dominant nations over the weak. There was no 'science of International Relations' ... The subject so-called was an ideology of control masking as a proper academic discipline.

Appropriately, Carr critiques liberals of his time precisely for generating ideas that do nothing more than legitimise hegemony. To Carr, IR as a discipline only becomes relevant in a context when hegemonic (Western) powers are interested in governing the world. They therefore need concepts to help them make sense of 'the world' and also to help them legitimise their governing of the world.

Of course, drawing comparisons between the American hegemony and its relations with mainstream IR on the one hand, and the rise of China with the CS on the other, does not by itself justify the enterprise of the CS from the critical IR perspective. It is worth mentioning again that on various occasions critics like Cunningham-Cross and Callahan has been cautious about the CS as merely another familiar hegemonic design. ${ }^{73}$ At first thought, their concerns

\footnotetext{
${ }^{68} \mathrm{Kai}$ He, 'A realist's ideal pursuit', The Chinese Journal of International Politics, 5:2 (2012), p. 193.

${ }^{69}$ Peter S. Onuf, 'American exceptionalism and national identity', American Political Thought, 1:1 (2012), p. 77.

${ }^{70}$ Zhang, 'The rise of Chinese exceptionalism', p. 322.

${ }^{71}$ The links of IR scholarship to governments is a common pattern. See Arlene B. Tickner and Ole Wæver (eds), International Relations Scholarship around the World (London: Routledge, 2009).

${ }^{72}$ Quoted in Introduction by Michael Cox, Edward H. Carr, The Twenty Years Crisis, 1919-1939 (London: Palgrave 2016), p. xxix.

${ }^{73}$ In his most recent monograph, Callahan makes similar points again when discussing how his work goes beyond Eurocentrism. See William A. Callahan, Sensible Politics (Oxford: Oxford University Press, 2020). To Callahan, Eurocentrism refers to the excessive focus on criticism of the West in critical/visual IR scholarship. As Callahan notes, 'Eurocentrism increasingly is seen as a problem in IR, and much visual IR thus addresses this issue through a robust critique of Euro-American images of the non-Western Other' (ibid., p. 52). However, 'the critique of "Western universals" cannot produce any new universal theory' (ibid., p. 4). Therefore, Callahan believes that we should also examine the East in the same way. And since critical IR discourse characteristically generalises from Euro-American examples, his book mainly
} 
seem to represent a reasonable response to the CS from a critical perspective. Foucault notably contends that 'humanity does not gradually progress from combat to combat until it arrives at universal reciprocity, where the rule of law finally replaces warfare; humanity installs each of its violences in a system of rules and thus proceeds from domination to domination'. ${ }^{74}$ What he tries to remind us of is that, when one thinks of a successful resistance, that is, the dissolution of an old subjectivity, one merely produces a new subjectivity, another form of domination. In other words, according to Foucault, resistance to a form of domination produces another form of domination; there exists a circular relationship between domination and resistance. From this perspective, the development of the CS accompanied with the rise of China would potentially become another form of hegemony.

Nevertheless, if the enterprise of the CS as resistance against Western hegemony turns out to be another form of domination, then does that mean resistance is ultimately pointless? To put the question differently: How and to what extent can the rise of China together with its knowledge taken from the CS constitute an effective form of critical resistance against what we have normally taken for granted in IR? To answer those questions, it is worth looking into Bhabha's notion of 'mimicry'.

\section{A defence of the Chinese School of IR theory: Bhabha's mimicry}

For Bhabha, mimicry is a powerful tool to resist colonial authority. ${ }^{75}$ When the colonisers (hegemonic culture) and the colonised (inferior culture) come into contact, the colonisers try to put their cultural ideology above the colonised. ${ }^{76}$ The colonisers believe that they are more superior than the indigenous population, and the latter should be assimilated by the advanced culture and should learn colonisers' own values, cultures, and morals. In this sense, the imitation realises the mission of enlightenment by copying and learning the colonisers' culture. The attitude of the colonisers is contradictory and ambivalent, however. On one hand, they encourage the indigenous populations to imitate themselves. Yet they are simultaneously afraid of being imitated, worrying that the latter will become their own 'clones'. In colonial India for instance, assimilation strategies were to produce 'British mimicers', but not the British themselves. To Bhabha, this distinction is important. On one hand, colonial discourse encourages and guides the improvement of the colonised to gradually approach the civilisation of the colonisers; on the other hand, it uses ontological differences and inferiority to resist the possibility of perfect imitation. 'Almost the same, but not quite. ${ }^{77}$ The colonisers governed the colonies under the banner of spreading the spirit of freedom and equality, but they would never give the indigenous people the same freedom and equality. The colonised knew this and therefore had to find ways to protect themselves from being further alienated and dominated by Western hegemonic culture. As a result, according to Bhabha, they employed a mimicry strategy as a form of resistance.

For Bhabha, 'mimicry' is a complex, ambiguous, and contradictory form of representation, and it is constantly producing difference/différance and transcendence. It is a strategy of appropriation and catachresis by indigenous people to resist colonial authority and to reshape their

\footnotetext{
focuses on Asian examples. Callahan uses many examples to illustrate this point. For example, when Hollywood movies in the West describe the East as a backward world, his book shows that Chinese movies do exactly the same thing, for example, Zhang Yimou's The Great Wall, wherein Europeans are presented as the Other: dirty and greedy thieves (ibid., p. 55). Callahan therefore concludes that China (and the non-West) is 'simply as a victim of imperialism', and that the Chinese and Asian alternatives are not “'emancipation” from Eurocentrism' (ibid., p. 56).

${ }^{74}$ Michel Foucault, Language, Counter-Memory, Practice (Ithaca, NY: Cornell University Press, 1977, p. 151.

${ }^{75}$ Bhabha, The Location of Culture.

${ }^{76}$ It is noted that the terminology of 'coloniser' and 'colonised' are dialectical and relational terms. For instance, China might be in a postcolonial situation against the West, but from places like Tibet and Xinjiang 'China' appears as a coloniser.

${ }^{77}$ Bhabha, The Location of Culture, p. 86.
} 
own identity. Bhabha quotes Jacques Lacan's view that 'the effect of mimicry is camouflage'. ${ }^{78}$ This disguise can deceive colonisers to a certain extent and give them a false sense of security. However, the indigenous will not fully accept the language, religion, values, etc. of the colonisers. Their mimicry is actually incomplete and partial. ${ }^{79}$ Bhabha reveals in detail the complex relationship between the coexistence of acceptance and resistance to colonial culture by indigenous peoples under colonial rule in his analysis of an event that occurred in the first week of May 1817, a story of the encounter between an early Western Christian and native Indians. In the story, native Indians have accepted the Bible, loved it, and learned about it spontaneously. However, the acceptance of the Bible by native Indians was not a complete acceptance, but a reserved acceptance. They accepted the Bible but did not want to admit that it was a gift from Westerners. They were also not interested in baptism. In particular, they resolutely rejected the sacraments that violated Muslim customs. Bhabha thus believes that the discovery of this Indian version of the Bible 'establishes both a measure of mimesis and a mode of civil authority and order' ${ }^{80}$ Interestingly, Bhabha's description of the strategy of 'mimicry' can be found in the CS.

Chinese IR scholars generally believe that although China seems to have acquired its own sovereignty, Western cultural hegemony still oppresses them in another form. The Western hegemony instils their ideology in the non-Western world, which gives the non-Western world a desire to imitate the West infinitely. These ideologies instilled involve various fields such as knowledge, language, education, etc. Therefore, if they do not take action to resist Western cultural hegemony, this results in complete inferiority. Consequently, they follow the mimicry strategy. From the works of Yan, Zhao, and Qin, we can see this process of mimicry. CS scholars use 'power', 'cosmopolitanism', 'relationality', and other concepts that are almost identical to those of mainstream IR theories. However, the connotations of those concepts are not exactly the same as the original Western meaning. Their mimicry is not a simple duplication of Western discourse, but uses the opportunity to imitate mainstream IR theories, pretending to enter the mainstream Western discourse. As Suparno Banerjee notes, "postcolonial mimicry" occurs when the less powerful colonial/postcolonial subjects displace the powerful colonisers' gaze by mimicking their actions, but never exactly becoming them. There always remains a difference between the original and mimicry, ${ }^{81} \mathrm{CS}$ scholars imitated Western theories, but at the same time they were also transforming Western theories to bring them more in line with China's conditions. As a result, CS scholars can make novel and innovative contributions to the literature of IR through hybridisation, mimicry, and the modification of the initial notions, as Helen L. Turton and Lucas G. Freire note. ${ }^{82}$ In the face of narcissistic Western authority, CS scholars (such as Yan, Zhao, and Qin, etc.) can prove that they are not inferior Others by showing their own traditional cultural values. Since it is imitation, it cannot be real. 'Almost the same, but not quite'. As Bhabha notes, 'the discourse of mimicry is constructed around an ambivalence: in order to be effective, mimicry must continually produce its slippage, its excess, its difference'. ${ }^{83}$

This mimicry is a concealed and destructive form of resistance in the anti-colonial strategy. First of all, CS's mimicry to the West is an internal disintegration of the West. It not only creates the 'similarities' between the CS (such as Yan's reconception of power, Zhao's reinterpretation of cosmopolitanism, and Qin's rearticulation of relationality) and the Western mainstream schools (that is, realism, liberalism, and constructivism), but also confuses the identity of the West. The

\footnotetext{
${ }^{78}$ Ibid., p. 85.

${ }^{79}$ Ibid., p. 91.

${ }^{80}$ Ibid., p. 107.

${ }^{81}$ Suparno Banerjee, 'Melodrama, mimicry, and menace: Reinventing Hollywood in Indian science fiction films', South Asian Popular Culture, 12:1 (2014), p. 17.

${ }^{82}$ Helen L. Turton and Lucas G. Freire, 'Peripheral possibilities: Revealing originality and encouraging dialogue through a reconsideration of “marginal” IR scholarship', Journal of International Relations and Development, 19:4 (2016), pp. 534-57.

${ }^{83}$ Bhabha, The Location of Culture, p. 86.
} 
relationship between the 'enunciator' and the one who is articulated can potentially be reversed. Under such mimicry strategy, if the power relations are not completely reversed, they will definitely be shaken. Meanwhile, the CS also verifies that the European experience is a local experience. Mainstream IR's concepts, ideas, and tenets are always produced in certain historical, political, and cultural contexts, and most importantly, they are produced in power structures. This is readily exposed when the starting points of mainstream IR - often taken for granted - are used in different contexts. Whether in support or in opposition, mainstream scholarship has been forced to respond to various ideas, concepts, and approaches to world politics and the study of it proposed by CS scholars. In this vein, the CS can indeed be seen as a set of examples where hybridity or mimicry occurs, 'a feature that, once noticed, helps us identify diversity on the periphery, and, more importantly, agency in marginal theory-making and theory-testing. ${ }^{84}$ As a result, from the perspective of Bhabha's colonial resistance, CS's mimicry uses imitation to alter mainstream (Western) theories and undermine its authority. In Bhabha's words, it poses an imminent threat to both 'normalised knowledge and disciplinary power', 85 thereby creating a heterogeneous articulated space, the so-called 'Third Place'.

To Bhabha, the Third Place is a space that blends different cultures and is full of tension; it can create new ideas and things through 'negotiation'. As Bhabha points out, cultural interaction can occur in cultural borderlands, where the meaning or value of culture may be misunderstood and cultural symbols may be misappropriated. In this zone, different cultures have always been in a state of constant communication and conflict. In this process, misreading and misappropriating cannot be avoided. However, such misunderstandings do not always bring about negative effects. Therefore, the Third Space itself is a cultural space that can not only accommodate cultural differences, but can also ultimately produce a new culture, that is hybrid, 'neither the one nor the other'. Arguably, post-Western IR including the CS is actually a sort of 'Third Space'. Taking the CS as an example, Yan's moral realism, Zhao's Tianxia and Qin's relationality all contain obvious mixed features. On the one hand, this hybridity has realised the continuous adjustment and reconstruction of the mainstream IR discourse. On the other hand, it also borrows and appropriates its various beneficial elements, rendering mainstream IR discourse ambiguous, mixed, and mutated, and eventually reaching the dissolution and even subversion of Western discourse.

Nevertheless, there seems to be an issue at the heart of the enterprises of the construction of CS (and other national schools too) from Bhabha's colonial resistance perspective. As Bhabha points out ${ }^{86}$

It is only when we understand that all cultural statements and systems are constructed in this contradictory and ambivalent space of enunciation, that we begin to understand why hierarchical claims to the inherent originality or 'purity' of cultures are untenable, even before we resort to empirical historical instances that demonstrate their hybridity.

From this perspective, Acharya's word of warning that global IR scholars should avoid repeating 'cultural exceptionalism and parochialism' represents a reasonable response to the CS from a critical perspective. ${ }^{87}$ Indeed, as shown earlier, the CS might essentialise and fixate on the existence of 'Chinese culture', which in essence is hybrid. A theoretical difficulty derived from this point of view is the extent to which a degree of essentialism is desirable.

Although Bhabha's views on mimicry and hybridity are insightful, deepening our understanding of colonial discourse and the possibility of resistance, it should be noted that he

\footnotetext{
${ }^{84}$ Turton and Freire, 'Peripheral possibilities', p. 552.

${ }^{85}$ Bhabha, The Location of Culture, p. 86.

${ }^{86}$ Ibid., p. 37.

${ }^{87}$ Acharya, 'Global international relations'.
} 
exaggerates the influence of the contradictory ambiguity of colonial discourse and overestimates the function of the micro-resistance of the colonised, and even elevates it to the point where it could destroy the structure of colonial rule. Notably, Foucault proposes a tactic that he calls, 'micro-politics', in which numerous local groups contest diffused and decentred forms of power spreading throughout society. Since power is plural and decentred, ${ }^{88}$ so must forms of resistance be. If power generates a multiplicity of effects, then it is only possible to resist those effects from below, at its most precise points of operation. Foucault therefore calls for a plurality of autonomous struggles waged throughout the micro-levels of society, and opposed linking these various struggles to form a unified 'counter-hegemonic bloc', in Gramscian terminology. However, as noted by Fredric Jameson, Foucault is trapped in a 'winner loses' logic: the more Foucault wins by portraying power as omnipresent and omnipotent and by stressing the circular relations between power and resistance, the more Foucault loses insofar as his critical voice of refusal becomes incompetent. ${ }^{89}$

Likewise, the problem with Bhabha's thought is that he ignores the asymmetric power relationship between the coloniser and the colonised. Bhabha's notion of hybridity is at best a marginal zone in a truly dualistic colonial relationship. No matter how much the identity of the coloniser and the colonised are disturbed, it is difficult to fundamentally change the true colonial relationship between ruler and ruled, between the hegemonic and inferior culture. Moreover, Bhabha also implicitly presupposes that the colonial/power relationship will eventually be broken regardless of whether the colonised actively resist or not, similar to Foucault's view which contends that resistance is in a position of interiority in relations of power. ${ }^{90}$ This is a problem. Because the colonisers can simply ignore the inherent contradictions of the colonial discourse, continue to carry out colonial rule unscathed, and stably (even with some interference present) maintain their self-identity. The Foucaudian or Bhabha-style of micro-resistance of the colonised is not enough to overthrow the overall structure of power relations. The subversion of the colonial power structure certainly requires hybrid microresistance, but it also requires dual oppositional resistance strategies and rebellious actions. From this perspective, one might ponder whether the CS can be regarded as a local group that contests diffused and decentred forms of Western hegemony and links various struggles to form a unified 'counter-hegemonic bloc', that is, post-Western IR. To avoid Foucault's and Bhabha's trap, we need to turn our gaze to Spivak's notion of 'reworlding' and strategic essentialism.

\section{A defence of the Chinese School of IR theory: Spivak's strategic essentialism}

Post-Western IR comes from the desire to 'reworld' a discipline dominated by the West that is imposed upon the non-Western world. ${ }^{91}$ Post-Western IR scholars have relied on Spivak contriving the notion of 'worlding' in their respective endeavours to challenge the Western-dominated field of IR. ${ }^{92}$ Spivak is critical of the literate constructions of the colonised population, the colonised subject that the colonial regime ascribed to 'the Third World'. She exposes the discursive technique undergirded by European imperialism that assigns a distant Other with an identity according to the division of the worlds (that is, the First World, Second World, Third World) that serves the operation of imperialism and colonialism. This is what she calls a 'worlding'

\footnotetext{
${ }^{88}$ Michel Foucault, 'Two lectures', in Colin Gordon (ed.), Power/Knowledge: Selected Interviews and Other Writing, 19721977 (Sussex, UK: Harvester, 1980), pp. 78-108.

${ }^{89}$ David C. Hoy, Critical Resistance: From Poststructuralism to Post-Critique (Cambridge, MA: MIT Press, 2005$)$, p. 9.

${ }^{90}$ Michel Foucault, History of Sexuality, Volume I: An Introduction (New York: Vintage, 1978), p. 151.

${ }^{91}$ For example, Tickner and Blaney rediscover painstakingly those geo-cultural sites each displaying a peculiar way of mapping its world differently constituted by Western international relations. See Tickner and Blaney (eds), Thinking International Relations Differently.

${ }^{92}$ Gayatri C. Spivak, 'Three women's texts and a critique of imperialism', Critical Inquiry, 12:1 (1985), pp. $243-61$.
} 
process, a process that attempts to disguise its own workings so as to naturalise and legitimise Western dominance. In Spivak's own words

If these 'facts' were remembered, not only in the study of British literature but in the study of the literatures of the European colonizing cultures of the great age of imperialism, we would produce a narrative in literary history, of the 'worlding' of what is now called 'the Third World'. To consider the Third World as distant cultures, exploited but with rich intact literary heritages waiting to be recovered, interpreted, and curricularized in English translation fosters the emergence of 'the Third World' as a signifier that allows us to forget that 'worlding', even as it expands the empire of the literary discipline. ${ }^{93}$

Escaping from worlding therefore requires 'reworlding'. Reworlding tripartites in different empirical agendas: resistance, hybridity, and fluidity. For example, by voicing the indigenous relations that, through having been silenced, made possible the colonial worlding, one exposes and resists the exploitive, political, and constructed characteristics of Third World identities. Therefore, selfempowerment is enacted through rediscovering an essentially different self that instantaneously provincialises the colonial subjectivity. ${ }^{94}$ To retrieve precolonial identities would disturb one's place in the current division of worlds and risk losing one's identity that provides a sense of certainty in the imperialist system. A forgotten non-colonial past is always hidden but ready to be rejuvenated in the worlding trajectory.

However, as Shih Chih-yu and I note elsewhere, ${ }^{95}$ there are three caveats in the process of reworlding. The first caveat is that the precolonial world may collude with the colonial world. Secondly, reworlding can enable self-discovery by recording the hybrid practices in the field that reveal how the colonial rules are constantly revised and even reverted. The caveat of reworlding through hybridity is that, once the imperialist Other is undistinguishable, resistance is rendered senseless, too. Thirdly, reworlding can indeed show how different worlds are relationally constituted but each informed in their own fluid discourse to the extent that one can neither claim autonomy nor achieve dominance. The caveat of reworlding through fluidity lies in the unassertive identities that can be too weak to engage in collective reflections.

Hence, in order to meaningfully challenge the hegemony, we need a site of agency, or a subject. The widespread influence of poststructural thought has challenged earlier Enlightenment notions of a unified, transcendent subject. Poststructural thought has opened the door for critical approaches to look at the manifestations of human subjectivity as fluid and multiple. The fluidity of the human subject, however, is not without its bounds or constraints. The same line of poststructural thinking that served to decentre the Enlightenment subject also suggests that the subject can be moored, at least temporarily, into a particular subject position within which it becomes identifiable and intelligible so as to, at times, resist hegemony. For instance, to make sense of the resistance against the normalised notion of heterosexuality, one must assume a collective identity of homosexuality as separate from heterosexuality.

Indeed, a pursuit of the CS reminds one of a potential danger that commonly lies in the different strings of post-Western IR, that is: to essentialise and fixate the existence of the Self, which in essence is fluid and multiple. As shown in the first section, the main advocates of the CS such as Yan, Zhao, and Qin have indeed juxtaposed China and the West, believing that there can be a 'distinctive' Chinese world order. As shown in the second section, critics have identified that such attempts certainly produce another problematic dichotomy. When Orientalist IR meets

\footnotetext{
${ }^{93}$ Ibid., p. 269.

${ }^{94}$ Dipesh Chakrabarty, Provincializing Europe: Postcolonial Thought and Historical Difference (Princeton, NJ: Princeton University Press, 2007).

${ }^{95}$ Chih-yu Shih and Yih-jye Hwang, 'Re-worlding the "West” in post-Western IR: The reception of Sun Zi's The Art of War in the Anglosphere', International Relations of the Asia-Pacific, 18:3 (2018), pp. 421-48.
} 
Occidentalist IR, hatred and conflict will become possible and perpetuate questionable practices in world politics. In that context, the enterprise of the CS might close down the creative space needed to imagine a different way of engagement as Bhabha has proposed. In the dualistic circuit of mainstream IR perspectives, the Self s epistemological violence towards the Other is often justified in practice. This way of thinking conditions everyone to regard the relationship between the Self and the Other as an inevitable clash and obscures the process of learning that has led both the West and China to transform themselves. As Andrew Hurrell rightly pointed out in his critique of Global IR, the search for non-Western IR can 'lead to a cultural and regional inwardness that may work to reproduce the very ethnocentricities that are being challenged'. ${ }^{96}$

Undeniably, the CS as well as post-Western IR in general has manifested several degrees of essentialism. Essentialism is almost something of a taboo in the critical line of IR scholarship. However, when critical theory's criticism of essentialism and the deconstruction of identity are too extreme, it may threaten the base on which the resistance depends. In order to have meaningful resistance, the indigenous identity needs to be strategically essentialised in order to support 'collective' rights, though only temporarily and strategically. In turn, strategic essentialism will legitimise the various claims that indigenous groups make in today's world politics. Cultural difference and recognition become explicitly tied to recognition as a group with rights. Indigeneity, as a politically salient category and identity, creates the space for mobilisation, contention, the (re) claiming of rights, and necessitates a certain framing for the interaction and contention that will occur in the movement's life. Spivak refers to this use of a fixed identity as 'strategic essentialism'. ${ }^{97}$

To Spivak, essentialism is the object to be deconstructed, however, deconstruction depends on essentialism. Spivak was influenced by Foucault in that she respects differences and opposes all dualism and essentialism. To her, essentialism is a trap. ${ }^{98}$ However, when resistance shows limitations in real situations, Spivak believes that a choice needs to be made. As she stated ${ }^{99}$ 'I think it's absolutely on target to take a stand against the discourse of essentialism ... But strategically, we cannot'. On the issue of feminism, Spivak opposes the so-called feminine nature. She believes that it is practically impossible to define women. An implication of defining women is creating a strict binary opposition, a dualistic view of gender and as a deconstructionist, she is against implying such dualistic notions. ${ }^{100}$ Although she opposes defining an absolute and fixed nature of women, from the standpoint of political struggle, she believes that the historical and concrete nature of women still exists and can be used as a weapon of struggle. As a result, Spivak makes a reconciliation between the political struggle of feminism and poststructuralism, arguing that in the fight against the patriarchal society and fighting for women's rights and interests, we still need the unity of women and to regard 'female' as a category that is a unifying slogan of struggle. In other words, although the bodies that are currently categorised as 'women' are simply a set of diverse and individual human beings, we still need to a unified category to pull together all those with similar lived experiences in order to fight for rights and progress beyond the oppressive forces that seek to quiet those with a body of a particular sex. Strategic essentialism is therefore helpful to feminists to deal with the contradictions in the postmodern situation.

In light of Spivak's thought, there is nothing wrong with the CS (or non-Western IR in general) itself. The disadvantage is the improper use of the CS which might stem from the school coming to be seen as a fixed entity and category, unfluid in nature. To defend the enterprise of the CS is to admit that we must adhere to essentialism to some degree. This can be done as

\footnotetext{
${ }^{96}$ Andrew Hurrell, 'Beyond critique: How to study global IR?', International Studies Review, 18:1 (2016), p. 150.

${ }^{97}$ Gayatri C. Spivak, Selected Works of Gyatrti Chakravorty Spivak, ed. D. Landry and G. MacLean (London: Routledge, 1996), pp. 204-05.

${ }^{98}$ Gayatri C. Spivak, In Other Worlds: Essays in Cultural Politics (New York: Methuen, 1987), p. 89.

${ }^{99}$ Gayatri C. Spivak, The Postcolonial Critic: Interviews, Strategies, Dialogues, ed. S. Harasym (New York and London: Routledge, 1990), p. 11.

${ }^{100}$ Spivak, The Postcolonial Critic.
} 
long as we stay alert to its dangers. In other words, strategic essentialists are actually antiessentialist, but regard 'essentialism' as a strategy adopted in specific situations to achieve the purpose of resistance. In this vein, the CS as a 'strategy' is not permanent but is specific to the situation of non-Western voices needing to be heard on the global stage. Just like Spivak said, ${ }^{101}$ 'If one is considering strategy, one has to look at where the group ... is situated when one makes claims for or against essentialism. A strategy suits a situation; a strategy is not a theory.' Thus, the CS as strategic essentialism can be seen as a means for mobilisation of struggle, but it cannot be fixed, sanctified, or axiomaticised. As a form of 'theory', CS exists for the sake of inspiring resistance and enabling reflections and presumably fades in a world where a hegemonic power takes a different shape, noting that the main challenge in the IR discipline today is to address the legacy of 'Western hegemony'. Conceived in this way, reworlding China, or the pursuit of the CS, reveals an unproblematised origin in the West, complicating those concepts familiar to Western IR and de-essentialising the categories on which Western IR relies to theorise. It is not an end, but a means. Once fixed, sanctified, or axiomaticised, it will show its limitations. The essentialist strategy adopted to achieve the purpose of the struggle cannot be turned into a permanent truth, as it will obliterate the differences internally, and perhaps, like Callahan said, produce another 'hegemonic design'.

Thus, there is no need to discard Chinese IR perspectives altogether as much current critical IR scholarship does. Dismissing the CS prematurely risks reinforcing the hegemonic discourse of Eurocentrism, as Spivak shows in her studies of Western white feminism. Using strategic essentialism, Spivak criticised white Western feminists, using French feminists as an example, for their hidden Eurocentrism that is intrinsic to the predominant and normalised principles of feminism which are then, problematically, taken to be universal truths on how to emancipate women. In the article, 'French Feminism in an International Frame', ${ }^{102}$ Spivak condemns Julia Kristeva's description of Chinese peasant women in her book About Chinese Women. As Spivak notes, Western feminists attempted to speak on behalf of the silent women of the Eastern subordinates but in fact they viewed themselves as mirror images. In other words, Western feminists were concerned about their own problems, not their subordinate's problems. As a consequence, they operated in collusion with the imperialist discourse and the subordinate women further lost their right to speak. ${ }^{103}$ Spivak therefore pointed out that the Western and elitist feminist theory is useless for 'Third World' women and even indirectly plays a harmful role. ${ }^{104}$

In short, the rise of the CS has stimulated discussions, ignited debates, and sparked inspiration among IR scholars. It has challenged the Western hegemony within international relations as well as the study of it. It is important to note that 'everything is dangerous' in Foucauldian terms, but everything is not equally dangerous at the same time. There should be a hierarchy of dangerousness. As pointed out at the inception of this article, the field of IR theory has been highly Eurocentric to date and international relations are dominated by the Western hegemony. Thus rather than discarding the CS or treating it as a purely objective standpoints that produces truths, we need to use it strategically and critically. IR knowledge of all sorts needs to be produced with a reflective spirit.

\section{Conclusion}

The recent development of the national schools in IR is not new. The CS is not the first attempt of this kind. The development of national schools in IR is derived from growing dissatisfaction with mainstream IR and self-reflection within the IR discipline. It is located within a larger effort to

\footnotetext{
${ }^{101}$ Gayatri C. Spivak, Outside in the Teaching Machine (New York: Routledge, 1993), p. 4.

${ }^{102}$ Gayatri C. Spivak, 'French feminism in an international frame', Yale French Studies, 62 (1981), pp. 154-84.

${ }^{103}$ Spivak, 'Three women's texts'.

${ }^{104}$ Spivak, In Other Worlds, p. 150.
} 
move away from Anglo-American-centrism, Eurocentrism and Western-centrism, while creating an indigenous, or simply non-/post-Anglo-American/Western IR theory and agenda. So, can the CS be regarded as a form of critical resistance against US/West hegemony? It certainly can. This article challenges the conventional wisdom in critical IR scholarship that the CS is just another familiar hegemonic design and therefore of questionable value to IR. From my perspective, this view is partial. The enterprise of the CS does indeed essentialise and fixate the existence of a 'Chinese culture' and has the potential to be another hegemonic construction based on Sinocentric ideology. Yet, it can still be an important local group in a wider effort to contest diffused and decentred forms of Western domination through linking various struggles to form a unified 'counter-hegemonic bloc' of post-Western IR in the discipline. The CS is not a perfect school of IR, but it might encourage IR scholars to rethink world politics from a new philosophical, geographical, and cultural perspective, and not take Western modes of thought for granted.

In our search for post-Western IR, it is necessary to have open communication between the critical IR theorists in the West and non-Western IR theorists (including the CS) in order to consolidate a collective spirit, or what could be called a 'counter-hegemonic bloc' of critical theory against mainstream IR scholarship. After the 1990s, Spivak paid more attention to the cooperation between feminist schools. Ten years after the publication of 'French Feminism in the International Framework', she reflects on her criticism of Western white feminism. ${ }^{105}$ She admits that her previous criticism of French feminism was too extreme. Spivak's change of attitude towards Western white feminists is inseparable from her own view of strategic essentialism. On the one hand, within feminism, everyone should talk about the differences between each other, in order to prevent the dominant group from generalising their own experiences and thus harming other women. On the other hand, feminists should unite and unify amongst themselves to fight for more political rights for the female collective. ${ }^{106}$ Spivak here clearly adopted strategic essentialism in her feminist research. When Western white feminist theories dominated the discourse, she warned us against Eurocentrism. And when feminists talked too much about differences and threatened collective unanimous external political action, she instead reminded everyone to pay attention to working together in unity. Spivak once pointed out indignantly that many people misunderstood and abused the phrase 'strategic essentialism', treating it as just 'an essentialist union ticket'. ${ }^{107}$ And yet, from here we know she claimed to have given up the phrase, although she did not give up using the concept in a reflective and responsible way.

To conclude this article, for post-Western (or non-Western, global) IR, strategic essentialism will not be outdated. The critical theory movement in IR has made great progress in striving for equal rights for non-Western countries through several decades of unremitting efforts. However, critical IR scholarship still has a long way to go. Due to the imbalance of development across different regions in the world, the differences and disputes among various groups in the critical IR scholarship will inevitably persist. With the judicious use of strategic essentialism, critical IR scholarship can form a collective that seeks common ground while reserving differences and fighting for common goals. However, when applying strategic essentialism, in addition to focusing on the differences between different (national) schools, we should also pay attention to the equality between people of different cultures and regional orientations; staying weary of harming other vulnerable groups in order to improve the status of certain countries, as seen in the case of the rise of China. From a Foucauldian perspective, the relations between resistance and domination can always be easily reversed. The CS might one day turn out to be another form of

\footnotetext{
${ }^{105}$ Spivak, Outside in the Teaching Machine, p. 144.

${ }^{106}$ Gayatri C. Spivak, Death of a Discipline (New York: Columbia University Press, 2003).

${ }^{107}$ Sara Danius and Stefan Jonsson, 'An interview with Gayatri Chakravorty Spivak', Boundary 2, 20:2 (1993), p. 35.
} 
domination in the near future. At that time, we will need to reflect on our reappraisal of the CS. Strategic essentialism will always be a powerful weapon in the critical tradition of the discipline of IR.

Acknowledgements. This article was originally presented at the 'Many Births of IR' workshop organised by Karen Smith and Vineet Thakur in Leiden. I would like to thank all the participants in the workshop, the editors and three anonymous reviewers of Review of International Studies, Ed Frettingham, Anthony O'Donnell, and Densua Mumford for their careful reading of earlier drafts of this article and their many insightful comments and suggestions. The author received no specific funding for this work.

Yih-Jye Hwang ( $\mathrm{PhD}$, Aberystwyth) is Universitair Docent of International Relations at Leiden University in the Netherlands. His research focuses on culture and identity politics in East Asia, East Asian approaches to human security, China's strategic and just war thinking, post-Western IR, post-structuralism, and theories of nationalism.

Cite this article: Hwang, Y.-J. 2021. Reappraising the Chinese School of International Relations: A postcolonial perspective. Review of International Studies 47, 311-330. https://doi.org/10.1017/S0260210521000152 